\title{
Experimental Investigation of RC Footings Resting on Sand Strengthened with Concrete Jacketing
}

\author{
Mohamed Attia Fouda ${ }^{*}, 1$, Mahmoud Elkateb ${ }^{1}$, Tamer Elkateb ${ }^{2}$, Ayman Khalil ${ }^{1}$ \\ ${ }^{1}$ Structural Engineering Department, Ain Shams University, 11311, Cairo, Egypt \\ ${ }^{2}$ Geotechnical Engineering Department, Ain Shams University, 11311, Cairo, Egypt
}

\begin{tabular}{l} 
A R T I C L E I N F O \\
\hline Article history: \\
Received: 25 September, 2020 \\
Accepted: 29 October, 2020 \\
Online: 08 November, 2020 \\
\hline Keywords: \\
Reinforced concrete footings \\
Stress distribution \\
Stress redistribution \\
Concrete jacketing \\
Bond \\
Dowels and Strengthening \\
Cohesionless Soil
\end{tabular}

\section{Introduction}

Strengthening of existing Reinforced Concrete (RC) footings is often conducted when there is a need to increase the loadcarrying capacity of such footings. Failure of RC footings is governed by bending, punching shear and one-way shear. The traditional way for strengthening, which is to increase the footing dimensions by adding a new layer of concrete on the top and sides of the existing footing, is an effective method for strengthening. The effect of the bonding technique, between existing and new concrete, on the stress distribution beneath strengthened footing is not known, and it is still based mostly on engineering judgment. This is due to the lack of sufficient research related to estimating stress distribution beneath strengthened footings. Bonding between existing and new concrete is considered as a main factor for load transfer, and for the concrete jacket to act as one part with the old concrete. The contact stress distribution beneath $\mathrm{RC}$ Footings resting on soil depends on the type of soil, as well as the "Corresponding Author: Mohamed Attia, attia87_2009@hotmail.com stiffness of the footing [1]. Previous research regarding strengthening of existing RC Footing has focused on improving punching and shear behavior [2-5]. In 2017, Gia Toai Truong [2] investigated the effects of inclined shear reinforcement, highstrength concrete, and additional concrete cast with amorphous metallic fibers (AMFs) on the punching capacity of existing footings, the authors stated that the effect of AMFs and high strength concrete on punching resistance was higher than the effect of using inclined shear reinforcement. In 2007, J. Hegger [3] investigated the punching behavior for rigid isolated $\mathrm{RC}$ footings resting on sand for different footing depths. The authors also developed a design model for assessing punching strength using the soil-structure interaction, and it was found that the contact stress distribution beneath the rigid footings rested on sand was higher at the center of the footing and lower at edges. In 2013, Bonic and Folic [4] studied the punching behavior on RC footings, subjected to concentric loading, resting on sand. This study showed that the actual punching failure load was higher than the expected failure load, calculated according to the international 
codes [5-7]. The authors stated that the theoretical assumption of uniform distributed stress under footing was conservative. In 2019, Wang-Xi Zhang [8] investigated the punching behavior of RC footings, subjected to eccentric loading, resting on rubber block. The results showed that the stress distribution was linear at low load levels, while it tends to be highly concentrated under the point of load application with load increase. Furthermore, the nonlinearly distributed stress influenced and increased the punching shear strength as well as the punching shear force of the footing. In 1990, Mosley [9] demonstrated the contact stresses distribution beneath a typical rigid footing resting on sand as shown in Figure 1.
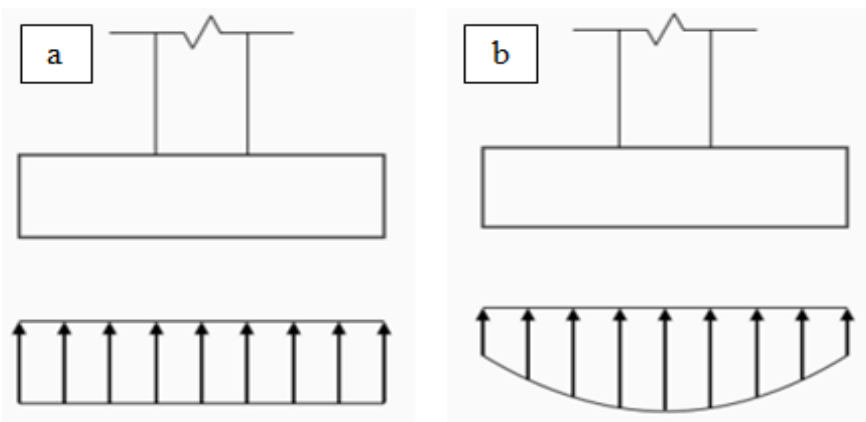

In 2015, Todor Vacev [10] investigated the punching behavior of rigid isolated RC column footings, subjected to concentric loading, resting on sandy soil, and found that the stress distribution beneath the footing was different from the theoretical assumption. However, the stresses were concentrated under center of the footing. In 1996, Muller, G. U. [11] analyzed the contact stress distribution under rigid square footings, resting on cohesionless soil, and subjected to eccentric and concentric loading. It was found that the stress distribution was concentrated under center of the footing for eccentric loading, instead of being uniform linear triangular as in the theoretical analysis.

Various codes world-wide [5-7] do not quantify the resistance load of elements repaired with each Strengthened method. Moreover, in all published studies, the variable overloading punching effect is usually examined. Therefore, it is required to measure and examine the influence of the interface surface on the redistribution of the contact stresses.
Dowels and epoxy bonding agent were selected to connect the interface of the jacketed elements based on the outcomes from previous research [12], [13]. In 2013, M.N. EL Siragy [14] assessed the settlement profile, shown in Figure 2, and loadcarrying capacity for rigid strip steel footings, resting on sand, after being strengthened with two steel plates from the sides. The authors found that the increase in the footing area led to reduction both the deformation and plastic flow of soil particles under the loaded footing.

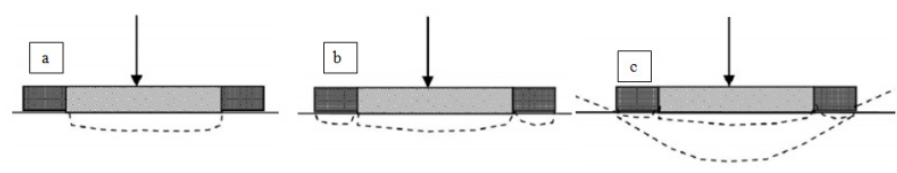

\section{Research Significance}

The current codes and design guidelines [5-7] do not account for the effect of strengthening on the load-carrying capacity and stress distribution beneath strengthened footings, so, in this study, full-scale footings were tested to study the real load-displacement behavior and stress distribution, as the behavior of a small footing will be different than that of a large footing when rested on sand medium under the same gravity load [15]. The current study also investigates the effect of using concrete jacketing for existing RC Footing, using both dowels and epoxy bonding agent or applying epoxy bonding agent only at the interface between the old and new concrete.

\section{Experimental Program}

\subsection{Geometry and detailing of tested samples}

Six full scale square reinforced concrete footing specimens were tested under concentric and eccentric static loading till failure. These footings were divided into two groups; each group consists of three footings, a control specimen and two footings strengthened by concrete jackets (with/without) dowels. Table (1) summarizes the test groups dimensions and illustrates the strengthening methodology. Concrete jackets were used to study the effect of dowels and the bonding agent, on the whole bonding strength under eccentric and concentric loads.

Table 1: Test Matrix

\begin{tabular}{|c|c|c|c|c|c|}
\hline Group & Symbols & $\begin{array}{l}\text { Dimensions before } \\
\text { strengthening } \\
(\mathrm{mm})\end{array}$ & $\begin{array}{l}\text { Dimensions after } \\
\text { Strengthening } \\
(\mathrm{mm})\end{array}$ & $\begin{array}{l}\text { Loading } \\
\text { Type }\end{array}$ & Strengthening Methodology \\
\hline \multirow{3}{*}{1} & $\mathrm{C} 1$ (control) & $1200 \times 1200 \times 400$ & \multirow{3}{*}{$1200 \times 1200 \times 400$} & \multirow{3}{*}{ 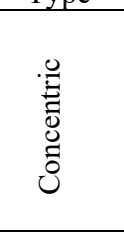 } & --- \\
\hline & G1F1 & $800 \times 800 \times 250$ & & & $\begin{array}{c}\text { Concrete jacket with shear dowels } \\
\text { on top and sides of existing } \\
\text { concrete. }\end{array}$ \\
\hline & G1F2 & $800 \times 800 \times 250$ & & & $\begin{array}{l}\text { Concrete jacket with shear dowels } \\
\text { on top of existing concrete only. }\end{array}$ \\
\hline \multirow{3}{*}{2} & $\mathrm{C} 2$ (control) & $1200 \times 1200 \times 400$ & \multirow{3}{*}{$1200 \times 1200 \times 400$} & \multirow{3}{*}{ 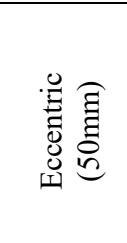 } & --- \\
\hline & $\mathrm{G} 2 \mathrm{~F} 1$ & $900 \times 1000 \times 250$ & & & $\begin{array}{c}\text { Concrete jacket with shear dowels } \\
\text { on top and sides of existing } \\
\text { concrete. }\end{array}$ \\
\hline & $\mathrm{G} 2 \mathrm{~F} 2$ & $900 \times 1000 \times 250$ & & & $\begin{array}{l}\text { Concrete jacket with shear dowels } \\
\text { on top of existing concrete only. }\end{array}$ \\
\hline
\end{tabular}


All reinforced concrete footings were tested on compacted dense sand inside a square wooden box with side length, and thickness of 2400 and $800 \mathrm{~mm}$ respectively. The box was strengthened with steel pipes from all sides. Figure 3-5 show the reinforcement details in all control and strengthened footings, Flexural reinforcement arrangement in the strengthened footings were constant and similar to the control specimens. Figure 6 shows the test setup for all footings. Each tested specimen was subjected to concentrated gravity load induced a vertical hydraulic jack, using load control mode, at which the load was increased by incremental values of $5 \mathrm{kN}$ until failure load level was attained.

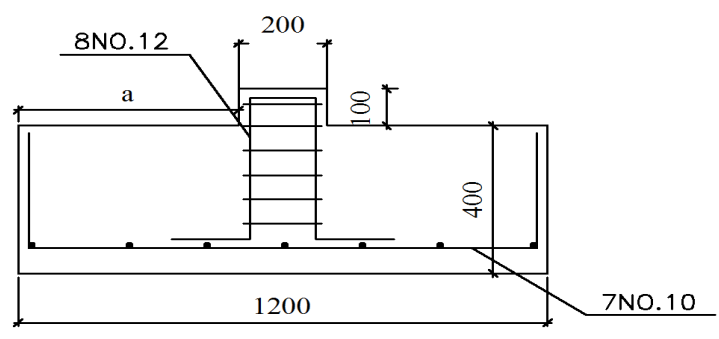

Figure 3: Reinforcement details for (a) $\mathrm{a}=500 \mathrm{~mm}$ for Control-1. $=450 \mathrm{~mm}$ for Control-2.
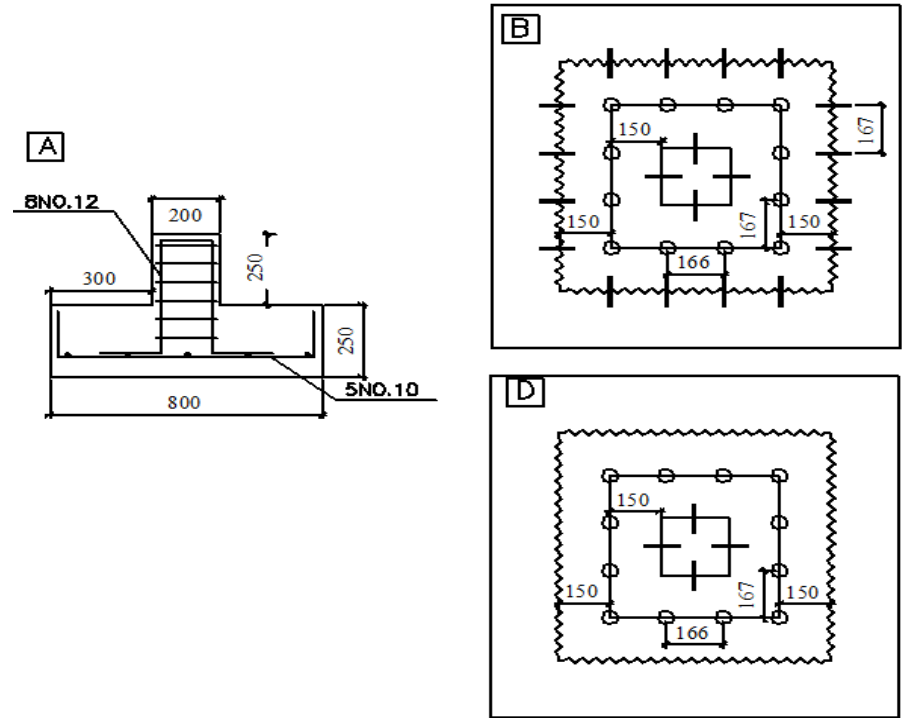

C

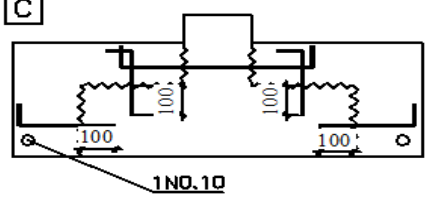

E

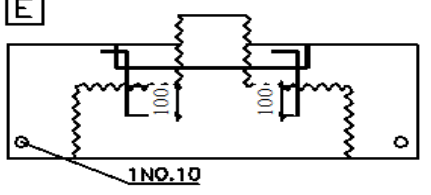

Figure 4: Reinforcement and dowel details for (a) G1F1and G1F2 before strengthening. (b) G1F1 after strengthening plan view. (c) G1F1 after strengthening elevation view. (d) G1F2 after strengthening plan view. (e) G1F2 after strengthening elevation view.
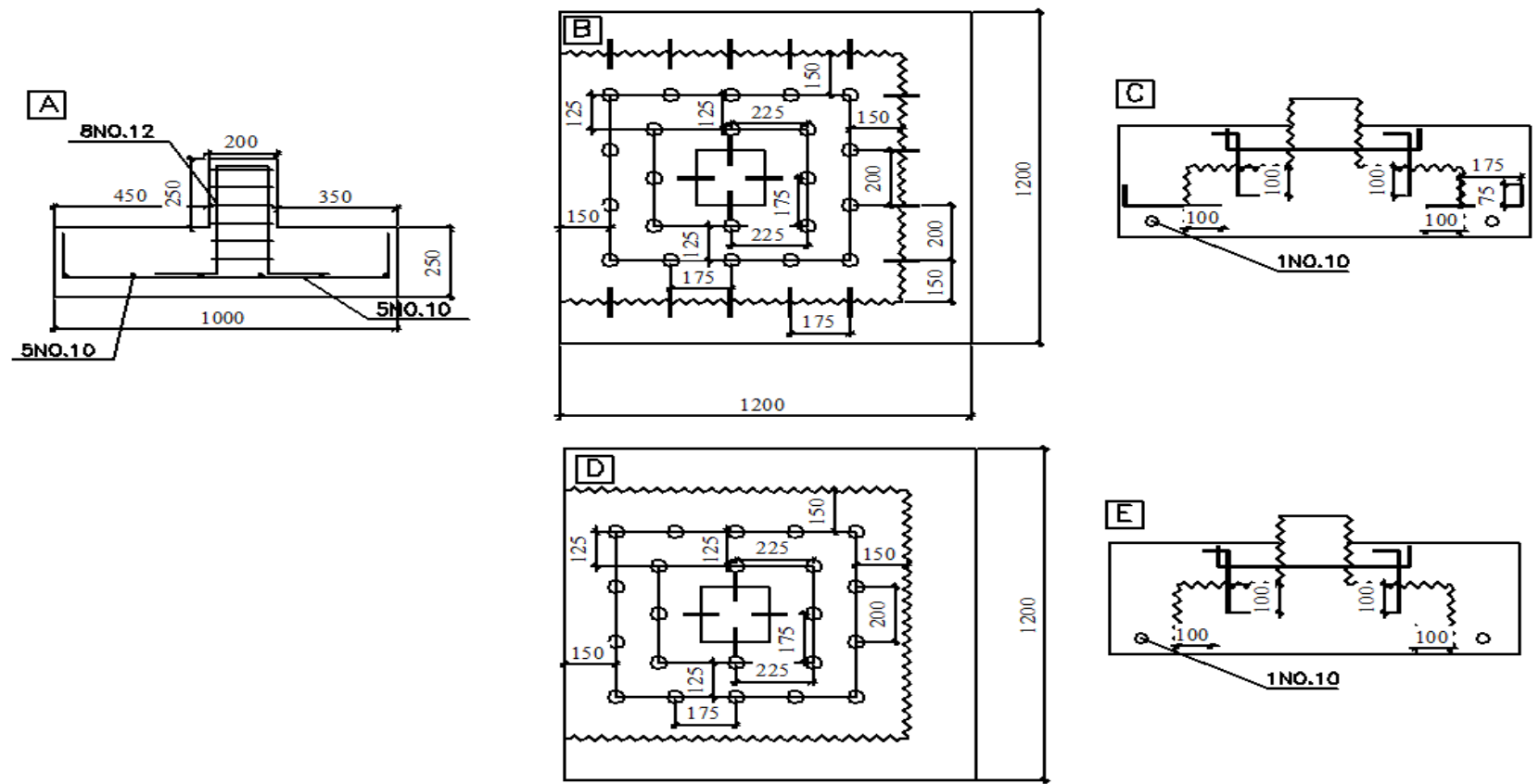

Figure 5: Reinforcement and dowel details for (a) G2F1and G2F2 before strengthening. (b) G2F1 after strengthening plan view. (c) G2F1 after strengthening elevation view. (d) G2F2 after strengthening plan view. (e) G2F2 after strengthening elevation view. 


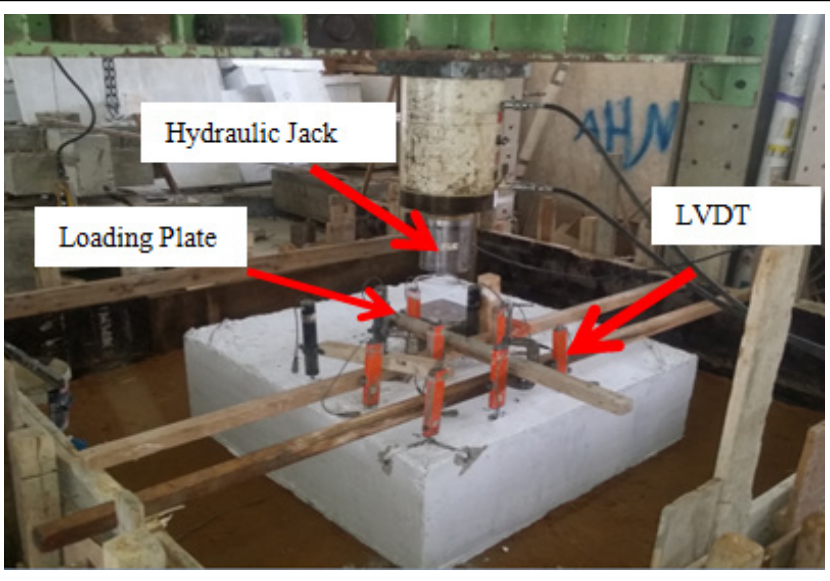

Figure 6: Experimental test setup.

\subsection{Materials}

\subsubsection{Properties of Sand}

Clean dense sand was used in the laboratory testing. The particle size distribution was determined through sieve analysis $(\mathrm{D} 60=1, \mathrm{D} 30=0.4$ and $\mathrm{D} 10=0.2$ ). The soil can be classified as well graded sand according to the Unified Soil Classification System (USCS) (ASTM Standard D2487, 2011) [16]. The density of the sand placed in the models was $20 \mathrm{kN} / \mathrm{m}^{3}$, while the friction angle was $43.9^{\circ}$, the friction was relatively high as the roughness coefficient between soil and concrete footing is responsible for increasing the bearing capacity of soil [17]. The soil was prepared and compacted up in layers of $250 \mathrm{~mm}$ thickness with vibrator machine as shown in Figure 7 , using $10.5 \%$ optimum water content.

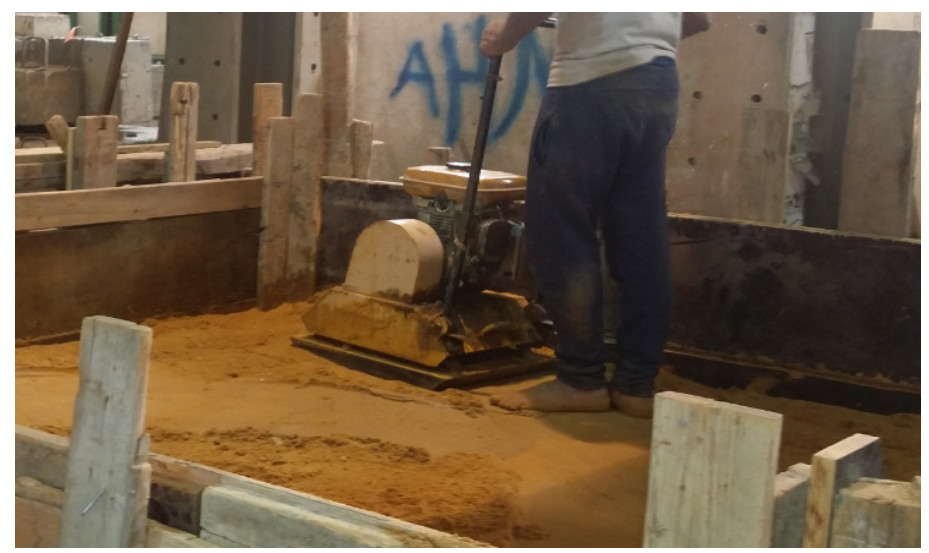

Figure 7: Compaction process

\subsubsection{Concrete}

The strengthened footings were cast in two stages. Initially, the concrete ingredients were mixed uniformly with proper proportions of $350 \mathrm{Kg}$ cement, $630 \mathrm{Kg}$ sand, $1260 \mathrm{Kg}$ crushed stone, and $175 \mathrm{Kg}$ water. The platform was cleaned, so that no foreign particle could be mixed with concrete. Precautions were taken during the placing and transportation of concrete so that consistency remained in the mixes, and to prevent segregation. Concrete was thoroughly compacted around reinforcement using electric vibrator. After 40 days, when the initial casting of concrete reached its ultimate strength, the concrete jacket was applied on existing footings using sikadur-32 epoxy bonding agent. During the initial casting and concrete jacketing operations, concrete cylinders and cubes were cast from each type of concrete mix. The actual compressive and tensile strength of concrete of individual footings were determined by testing of the corresponding cylinders and cubes on the day of casting the concrete jackets and on the day of testing. The measured characteristic compressive strengths $\left(f_{c u}\right)$ of original concrete, after 28 days, was $24.8 \mathrm{MPa}$, while it was $33 \mathrm{MPa}$ for the column stub. The compressive strength of the concrete jacketing was 25.2 $\mathrm{MPa}$, with a coefficient of variation (COV of about $8.2 \%$ ) based on 12 cubes tested according to the British Standards [18].

\subsubsection{Reinforcement}

$10 \mathrm{~mm}$ diameter deformed bars were placed at $50 \mathrm{~mm}$ cover as main reinforcement for all the footings and $12 \mathrm{~mm}$ diameter deformed bars were placed in column stub. The measured yield tensile strength $\left(f_{y}\right)$ of bars was $407 \mathrm{MPa}$ and the corresponding yield strain is 0.00205 , while the ultimate tensile strength was 611 MPa based on tensile strength test according to ASTM A615/ A615M [19].

\subsection{Surface preparation and installing dowel bars}

The preparation of the surface was done when the original concrete footing specimens were 35 days old. The surfaces of the $\mathrm{RC}$ footings were roughed by hand-chiseling from all sides and top surface. Dowel bars of $10 \mathrm{~mm}$ diameter and $250 \mathrm{~mm}$ length rod were installed in original footings between the interfaces of the layered construction. These bars were embedded into the initial cast concrete by drilling after 40 days of casting with 100 $\mathrm{mm}$ embedded length and were installed using sikadur-31CF (Thixotropic epoxy resin adhesive). Figure 8 shows surface perpetration process, dowels drilling and placement in original footing and casting concrete jacketing.

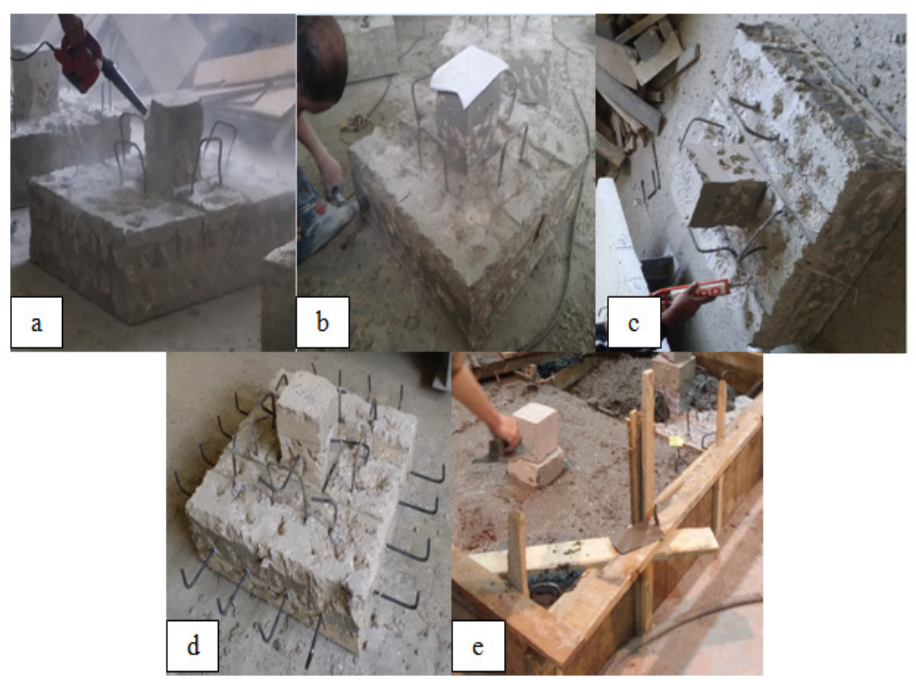

Figure 8: Preparation process (a) Roughening the concrete surface. (b) Drilling. (c) Installing epoxy. (d) Installing and placement dowels. (e) Casting new jacket.

\subsection{Instrumentation acquisition system}

The data acquisition system included two data acquisition modules for all the strains, displacements, and load cells. Ten 
LVDTs were used to record the vertical displacement. Figure 9 shows the distribution of LVDTs on group-1 and group-2 respectively.
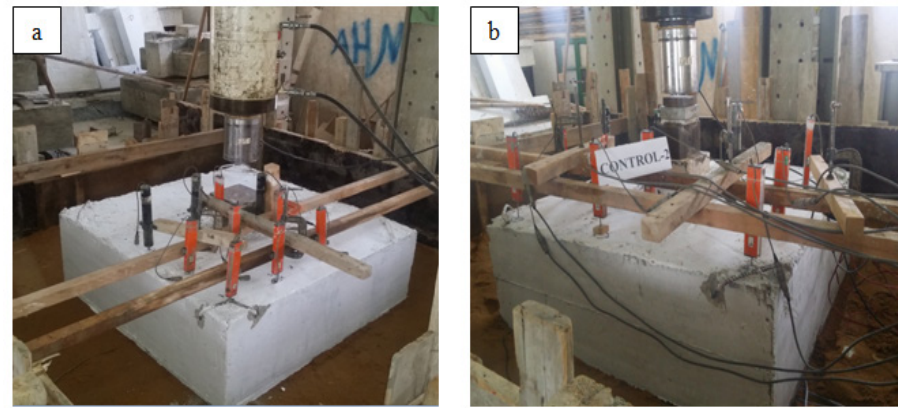

Figure 9: LVDTs distribution for (a) Group-1. (b) Group-2.

Concrete strain gauges were installed on the upper reinforced concrete footing on one direction only for group-1; strains were placed on to orthogonal direction for group- 2 as shown in Figure $10)$.
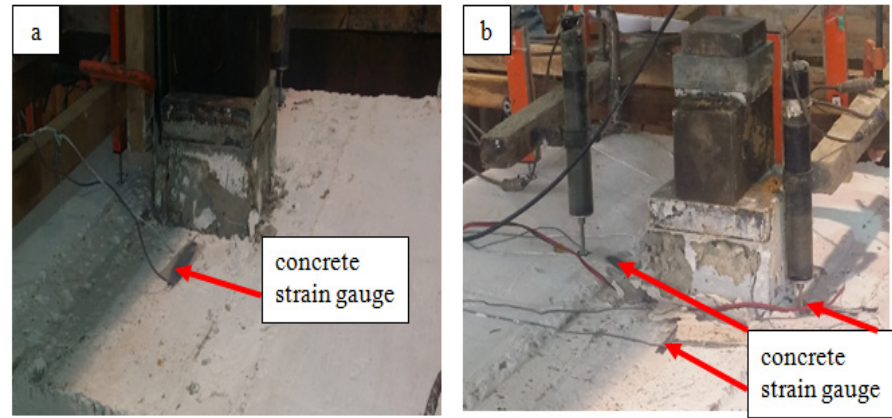

Figure 10: Concrete strain gauge distribution on (a) Group-1. (b) Group-2.

Reinforcement Strain gauges (6mm-length) were attached to steel rebar's in one direction for group-1 and in two orthogonal directions for group-2 as shown in Figures 11 ( $a$ and $b$ ) respectively. Figures 11 (c and d) show the distribution of additional reinforcement strain on the newly placed steel bars for strengthened footings G1F1, G1F2, G2F1 and G2F2.
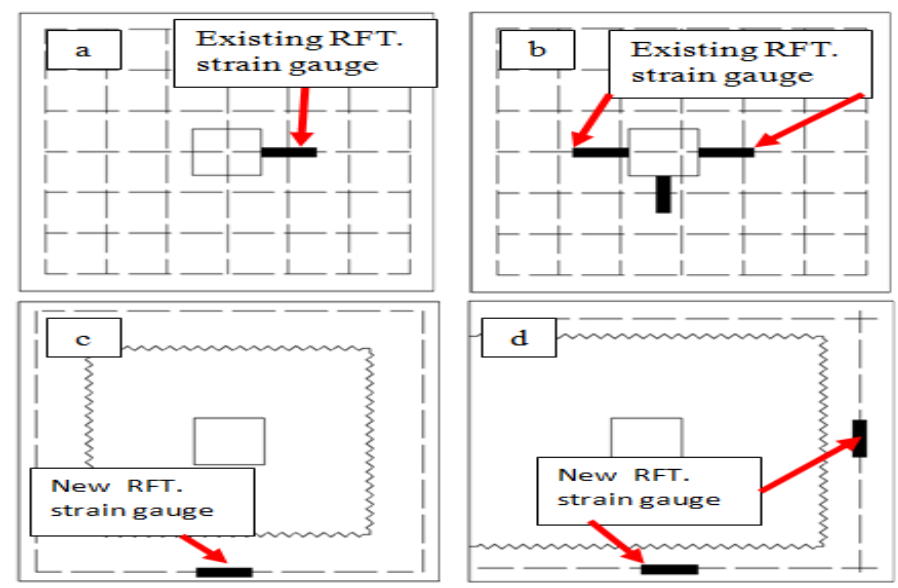

Figure 11: Reinforcement strain gauge distribution (a) Group-1. (b) Group-2. (c) Strengthening footing group-1. (d) Strengthening footing group-2.

Shear dowels, at typical locations, had strain gauges at their mid-length in longitudinal direction in specimen G1F1, while strain gauges were placed on shear dowels in orthogonal directions in specimen G2F1. Figure 12 shows a typical layout for strain gauge placed on shear dowels.

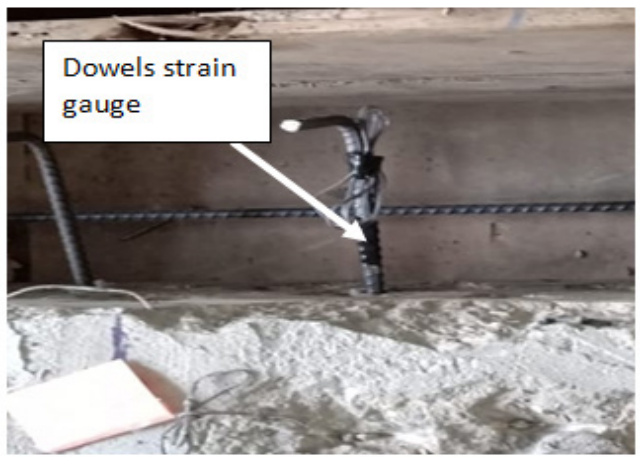

Figure 12: Typical reinforcement strain gauge placed on shear dowels

Figure 13(a) shows a TY-350 pressure cell placed between the reinforced concrete footing and the soil surface to determine the contact stress distribution below the footing. Thus, it was decided to cover a pressure cell with thin steel plate to protect the pressure cell from damage. Four soil pressure cells were distributed below the reinforced concrete footing for groups (1\&2) are shown in Figures (13) (b \& c) respectively.
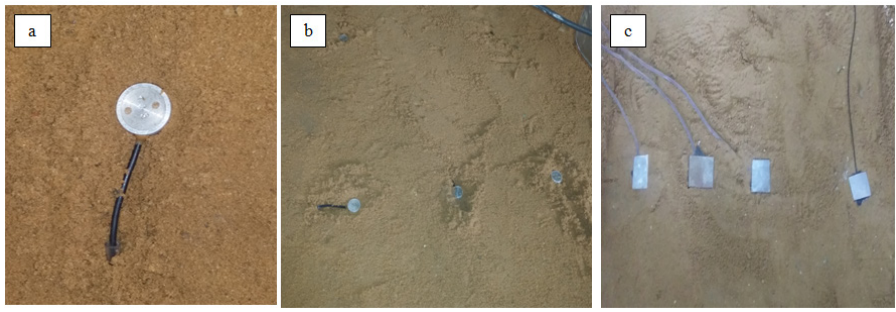

Figure 13: Distribution of load cell pressures beneath concrete footing (a) Typical TY-350 pressure cell. (b) (Group-1). (c) (Group-2).

\section{Experimental Results}

The application of concrete jacketing increased the ultimate load-carrying capacity of strengthened footings compared with those without strengthening. Moreover, the load-carrying capacity of G1F1 and G2F1 were higher than that of G1F2 and G2F2. However, the difference in the ultimate capacity was not significant. The increases in loading capacity are due to the increase in the concentration of stress at the center of the footing for footings in groups (1\&2). The actual moment is calculated using compatibility of ultimate strains, where the location of the neutral axis is determined, and the moment is calculated by multiplying the tension force times the moment arm.

\subsection{Failure modes and crack patterns}

All footings failed in flexure due to steel reinforcement yielding, no brittle failure and debonding for concrete jacketing was observed. All side cracks were observed during test, while cracking on bottom surface of footings were observed at the end of the tests. The stiffness of the footings decreased with propagation of cracks at increased load levels. Figure 14 shows the typical crack patterns at failure for each footing. The behavior of the strengthened Footings G1F1, G1F2, G2F1, and G2F2 was close to the control specimens in terms of the crack initiation, crack pattern and failure modes whilst having different failure 
loads. Increased strains in the flexural reinforcement were measured before failure. Experimental failure loads for different groups are listed in Table (2). Side cracks first appeared at bending moment level of about $50 \mathrm{kN} . \mathrm{m}$ in all footings and the corresponding load level were in the range of 700 to $800 \mathrm{kN}$. The theoretical moment at failure load, using the uniform distribution theory beneath footing rested on soil (Force/Area), was calculated as $\mathrm{WL}^{2} / 2$. From Table (2), it is noted that the actual moment at failure is equal to $82 \%$ of the theoretical moment which means the stress distribution under concrete footing resting on cohesionless soil was not consistent with the uniform distribution stress theory. Furthermore, the load-carrying capacity for all strengthened footing was higher than control samples, and the stress distributions under strengthened footing were the main reason for increasing the footing capacities.

\subsection{Reinforcement and Concrete Strains}

For all footings, compressive strains at the top side of the concrete were measured, in addition to the tensile strains of the lower main reinforcement. Figure 15 shows the applied load vs. the compressive strains of the upper side of the footing beside the column stub, showing a similar behavior for all footings under concentric loads. Regarding eccentric footings, the behaviour of the strains in the eccentric direction was different than that in the perpendicular direction, due to the concentration of stresses in eccentricity direction. Concrete crushing did not occur in all specimens and all compression strains did not exceed the plastic limit of 0.003. It was also noticed that the load-strain relationship was almost identical in the linear elastic stage.
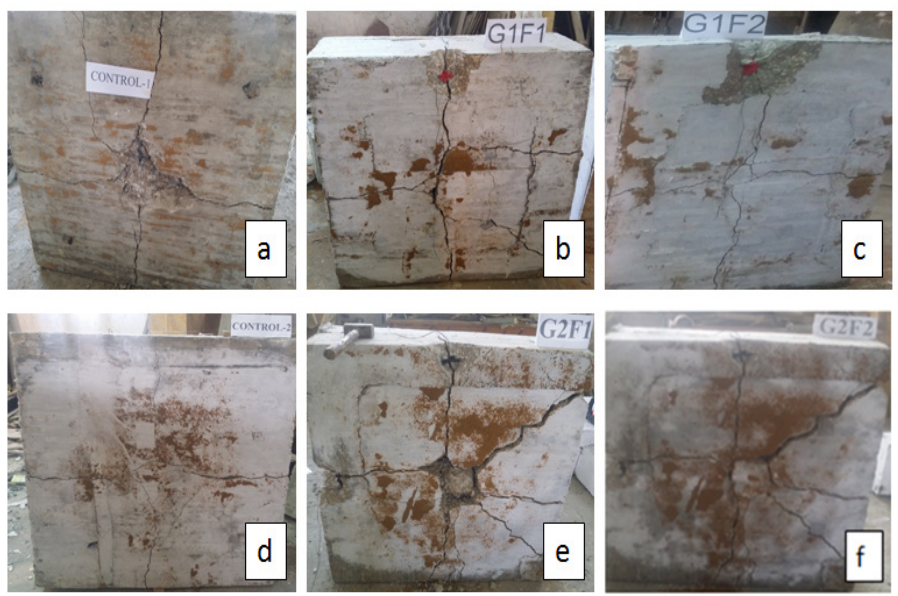

Figure 14: Typical cracking patterns at Failure for footings (a) C1. (b) G1F1. (c) G1F2. (d) C2. (e) G2F1. (f) G2F2.

Figure 16 shows the flexural reinforcement strains measured for concentric and eccentric footing. The strain gauges were installed within the column face region. All maximum measured strain values for existing reinforcements were above the yield limit which indicated that the failure occurred due to flexure, while all recorded strain values for dowels were below the yield strain limit, which indicates that the flexural debonding did not occurred during loading process.

Table 2: Test Results

\begin{tabular}{|c|c|c|c|c|c|c|}
\hline \multirow{3}{*}{ Group } & Label & $\begin{array}{c}\text { Failure } \\
\text { Load } \\
(\mathrm{kN})\end{array}$ & $\begin{array}{c}\% \\
\text { Increase } \\
\text { in load- } \\
\text { carrying } \\
\text { Capacity }\end{array}$ & $\begin{array}{c}\text { Theoretical moment } \\
\text { at failure using } \\
\text { uniform stress } \\
\text { distribution (kN.m) }\end{array}$ & $\begin{array}{c}\text { Actual } \\
\text { moment at } \\
\text { failure } \\
(\mathrm{kN} . \mathrm{m})\end{array}$ & $\begin{array}{c}\text { Max vertical } \\
\text { settlement at the } \\
\text { center of the } \\
\text { footing at control } \\
\text { peak load (mm) }\end{array}$ \\
\hline \multirow{3}{*}{1} & C1(control) & 921 & --- & 79.86 & 66.13 & 16.8 \\
\cline { 2 - 7 } & G1F1 & 994.5 & 7 & 79.86 & 66.51 & 17.78 \\
\cline { 2 - 7 } & G1F2 & 980 & 6 & 79.86 & 66.51 & 18 \\
\hline \multirow{3}{*}{2} & C2(control) & 1000 & --- & 79.1 & 66.5 & 17.4 \\
\cline { 2 - 7 } & G2F1 & 1051 & 5.1 & 79.1 & 66.13 & 17.95 \\
\cline { 2 - 7 } & G2F2 & 1020 & 2 & 79.1 & 68.24 & 18.1 \\
\hline
\end{tabular}
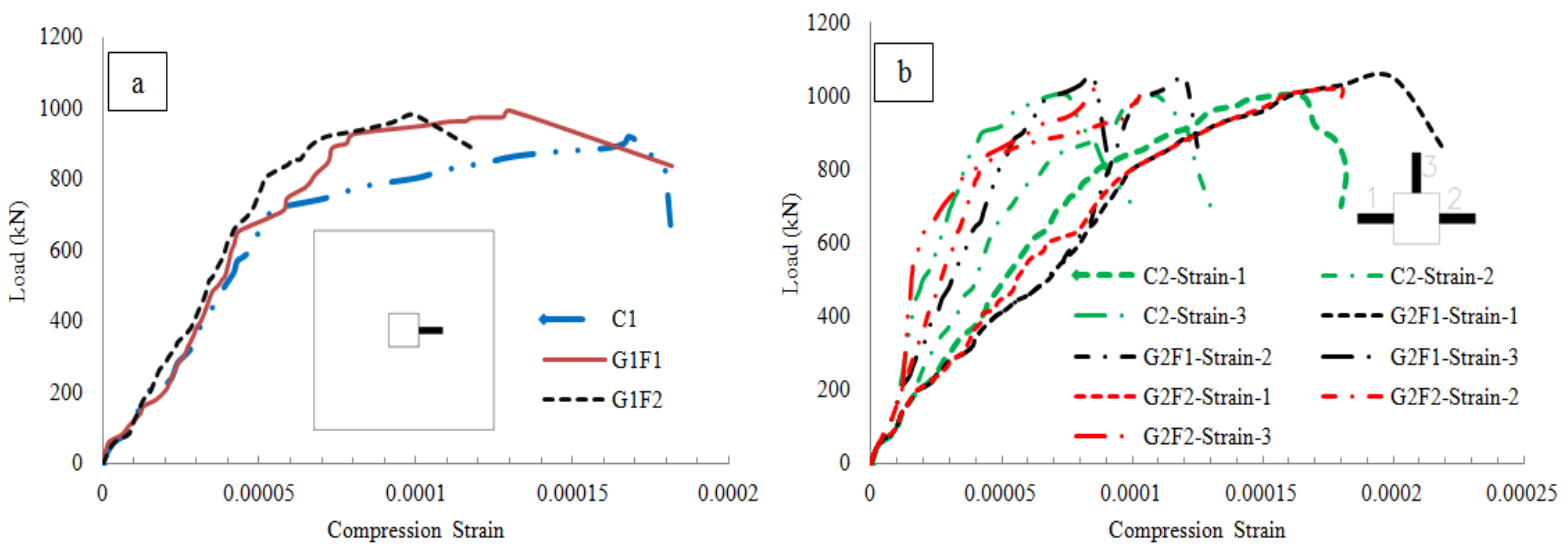

Figure 15: Applied load versus compressive strain (a) Concentric loading (b) Eccentric loading. 

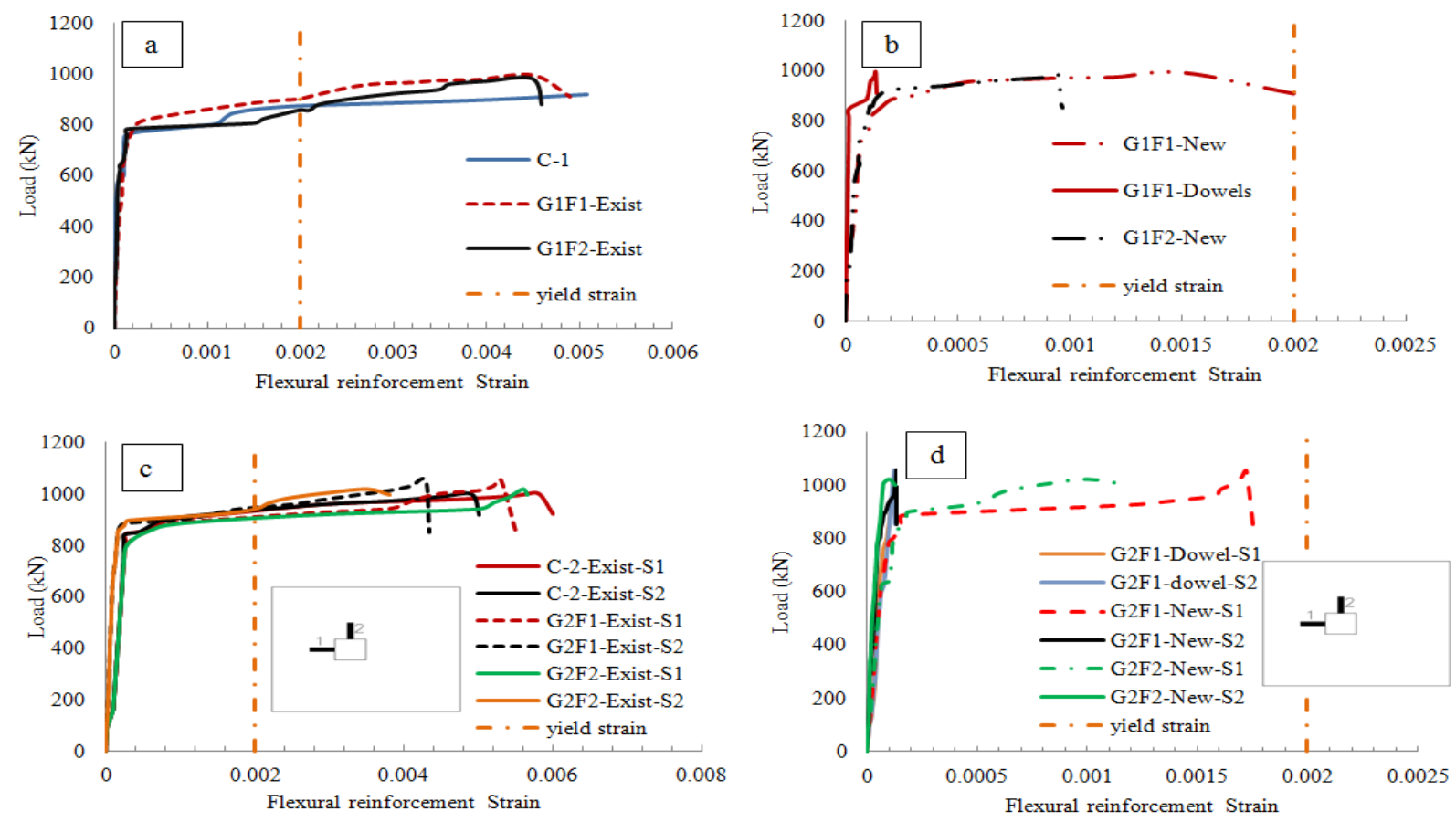

Figure 16: Applied load versus Flexural reinforcement strain (a) Existing reinforcement under concentric loading. (b) New reinforcement under concentric loading. (c) Existing reinforcement under eccentric loading. (d) New reinforcement eccentric loading.

\subsection{Settlement under concrete footing}

The settlement of the control and strengthened reinforcement concrete footing was determined at the same points along the width of the footing, as indicated in Figures 9 (a\& b) for concentric and eccentric footings. The normalized average settlement versus the applied load of the reinforced concrete footing is illustrated in Figure 17. The behaviors of the concentric and eccentric footing were in good agreement until a load level of about $400 \mathrm{kN}$. After that, due to the eccentricity effect, a clear deviation in measured average settlement between group-1 and group-2 was noticed. Before cracking of the concrete, the settlement of all points along the width of the footing was similar. The rate in increase in average settlement after cracking was higher than that before cracking.

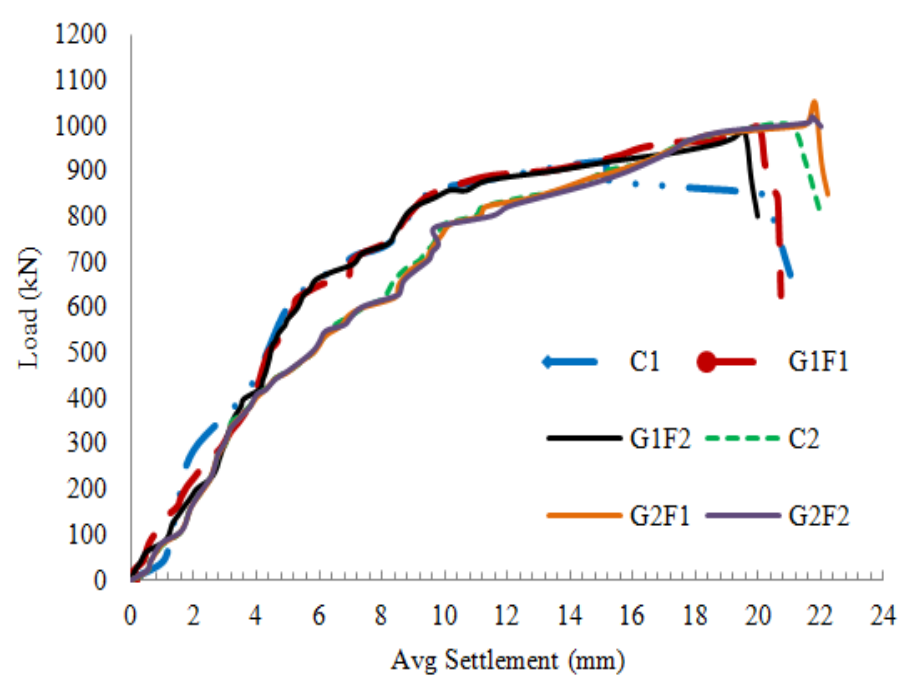

Figure 17: Applied load versus Average Settlement.
For the elastic stage, the behavior of all strengthened and control footings were similar and the elastic stiffness was almost the same according to the linear load-displacement relationship shown in Figure 17. After the concrete cracked, the behavior changed as the stiffness of the reinforced concrete footing decreased and the settlement significantly increased. Average settlements were not affected by using dowels compared with the footings strengthened with epoxy bonding agent only. The maximum settlement at the center of the footings increased with the increase in the contact stresses below the footings as shown in Table 2. The maximum settlement under strengthened footing G1F1, G1F2 were $5 \%$ and $7 \%$ higher than that of $\mathrm{C} 1$ respectively, while the settlement under strengthened footing G2F1, G2F2 were higher than that of $\mathrm{C} 2$ by $3 \%$ and $4 \%$ respectively.

\subsection{Contact Pressure Distribution}

The contact Stress distribution below control and strengthened concrete footing using concrete jacket with/without dowels were measured using pressure gauges as shown in Figure 13. Figure 18 shows the shape of contact stress distribution at center line of the footing for group- 1 at $50 \%$ and $100 \%$ of the ultimate load of the control specimen $\mathrm{C} 1$.

Figure 18 shows the behavior of contact stress pre and post cracking. There was no crack initiation observed at $50 \%$ of the failure load of $\mathrm{C} 1$. The recorded stress at center line of footing $\mathrm{C} 1$ was close to the theoretical uniform stress distribution, but the stress at the edge was less than the theoretical assumption. The stress under center of strengthened footing G1F1 is higher than C1 by $9 \%$ and $12 \%$ in cases (a) \& (b) respectively. Moreover, The stress under edge of strengthened footing G1F1 is lower than $\mathrm{C} 1$ by $16 \%$ in case (a) and $22 \%$ in case of (b) which means the contact surface between existing and new concrete play an important role in stress distribution under strengthened footing. 
The stress under center of strengthened footing G1F2 is higher than that of $\mathrm{C} 1$ by $18 \%$ in case (a) and $13.5 \%$ in case (b). While, the stress under edge of strengthened footing G1F2 is lower than that of $\mathrm{C} 1$ by $23 \%$ and $25 \%$ in cases (a) and (b) respectively. The ratio between the center to the edge stress increased with increasing the applied load, which is due to that the effect of cracking. The flexibility of the footing increased with increasing the flexural cracks leading the concentration of the stress to be shifted towards the center of the footing. It is noticed that for the control footings in group-1, the shape of contact stress before cracking was saddle-shaped, but after cracking the shape of contact stress takes place as a parabolic shape for control footing, while the contact stress was a bell shape beneath strengthened footings. Figure 19 shows the shape of contact stress distribution at edge line of the footing for group- 1 at $50 \%$ of $\mathrm{C} 1$ failure load and $100 \%$ of $\mathrm{C} 1$ failure load.

From Figure 19, it is noticed that the recorded stress at center line of $\mathrm{C} 1$ seems close to the theoretical uniform stress distribution assumption. The stress under center of strengthened footing G1F1 is less than that of $\mathrm{C} 1$ by $16 \%$ in case (a) and $22 \%$ in case of (b). Additionally, the stress under edge of strengthened footing G1F1of above figure is lower than that of $\mathrm{C} 1$ by $5 \%$ in case (a) and $22 \%$ in case of (b). The stress under center of strengthened footing G1F2 of the above figure is lower than $\mathrm{C} 1$

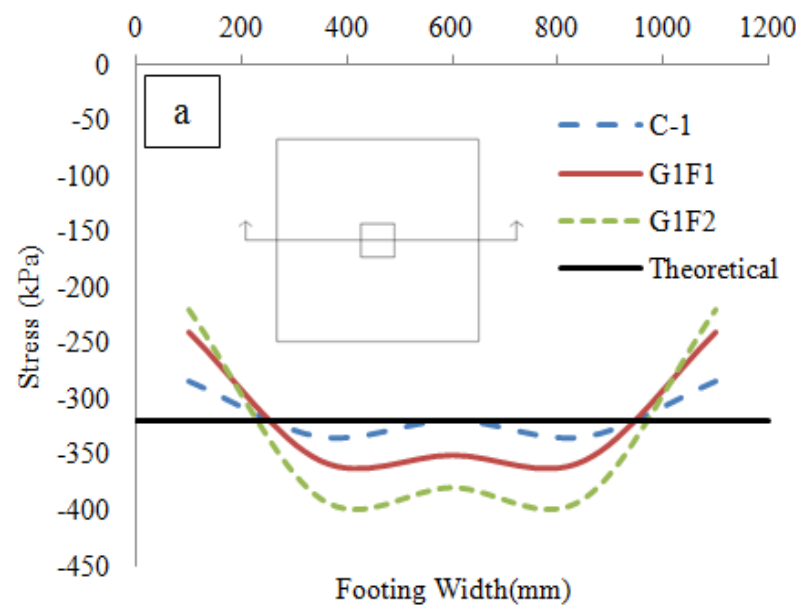

Figure 18: Contact stress distribution beneath footing center line (group-1) at (a) $50 \%$ of $\mathrm{C} 1$ failure load (b) $100 \%$ of $\mathrm{C} 1 \mathrm{failure}$ load.
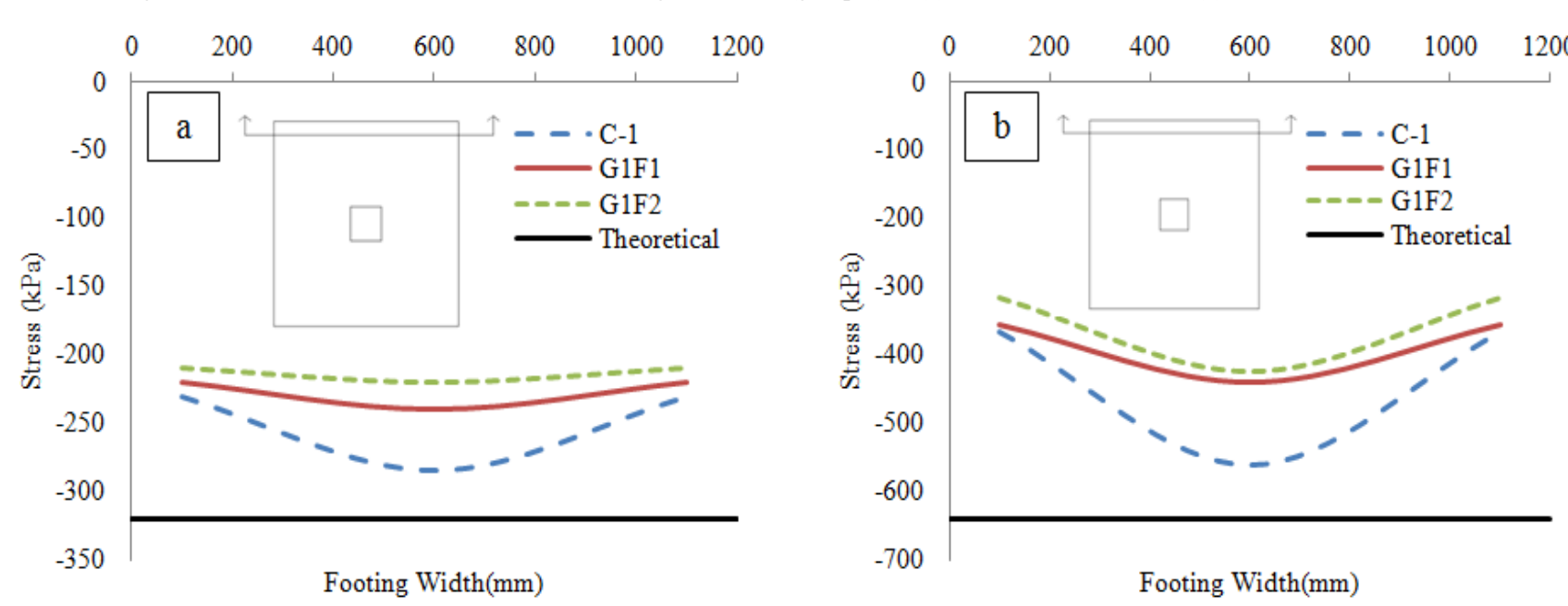

by $23 \%$ in case (a) and $25 \%$ in case of (b). Furthermore, the stresses under the edge of strengthened footing G1F2 are lower than that of $\mathrm{C} 1$ by $9 \%$ and $15 \%$ in cases (a) and (b) respectively.

Figure 20 shows the shape of contact stress distribution at the center line of the eccentric footing for group- 2 at $50 \%$ and $100 \%$ of the failure load of the control specimen $\mathrm{C} 2$. The stress distribution under eccentric loading is concentrated under the column and completely different than the theoretical assumption $(\mathrm{MY} / \mathrm{I})$, these results were in agreement with the experimental results for non strengthened footings by G. U. Muller et al. [11]. The stress concentration under center line of column stub for $\mathrm{G} 2 \mathrm{~F} 1$ and $\mathrm{G} 2 \mathrm{~F} 2$ is higher than that of $\mathrm{C} 2$ by $1 \%$ and $5 \%$ respectively for case (a) and $2 \%$ and $5.6 \%$ respectively for case (b). Moreover, the stress concentration under footing edge at maximum compression zone G2F1 and G2F2 is higher than that of $\mathrm{C} 2$ by $1.5 \%$ for case (a), while it is lower than that of $\mathrm{C} 2$ by $2 \%$ and $6 \%$ respectively for case (b). The stress concentration under footing edge at minimum compression zone G2F1 and G2F2 is lower than $\mathrm{C} 2$ by $16 \%$ and $23 \%$ respectively for case (a) and lower than $\mathrm{C} 2$ by $18 \%$ and $25 \%$ respectively for case (b).

Figure 21 shows 3-Dimensional Contact stress distribution beneath control footings $\mathrm{C} 1$ and $\mathrm{C} 2$ at $50 \%$ and $100 \%$ of their failure loads using Surfer maps version 13.

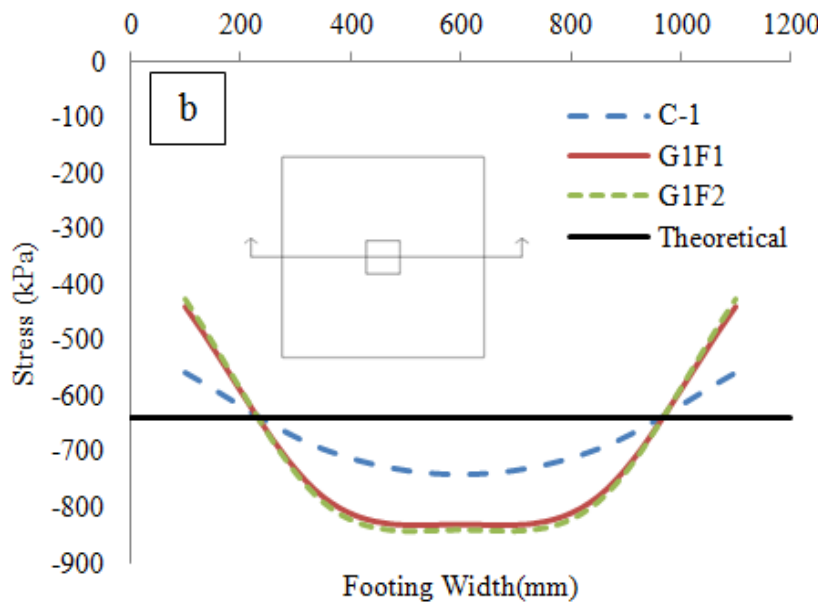

Figure 19: Contact stress distribution beneath footing edge line (group-1) at (a) $50 \%$ of $\mathrm{C} 1$ failure load (b) $100 \%$ of $\mathrm{C} 1$ failure load. 

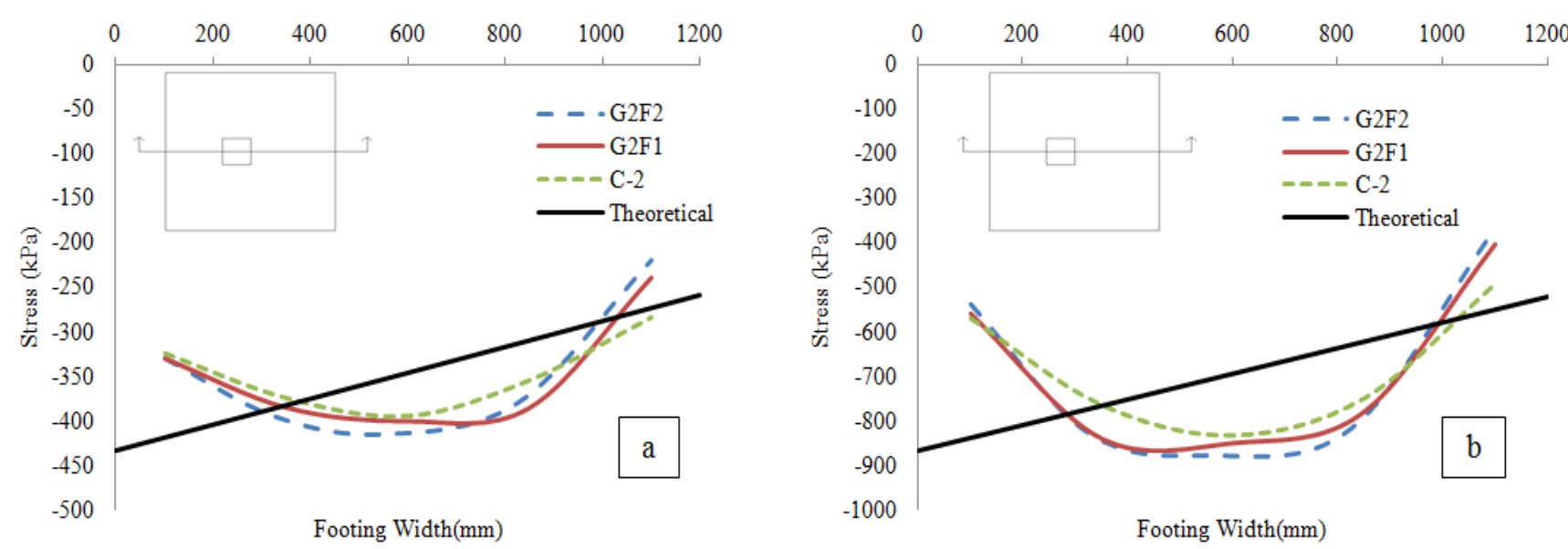

Figure 20: Contact stress distribution beneath footing center line (group-2) at (a) 50\% of C2 failure load (b) $100 \%$ of C2 failure load.
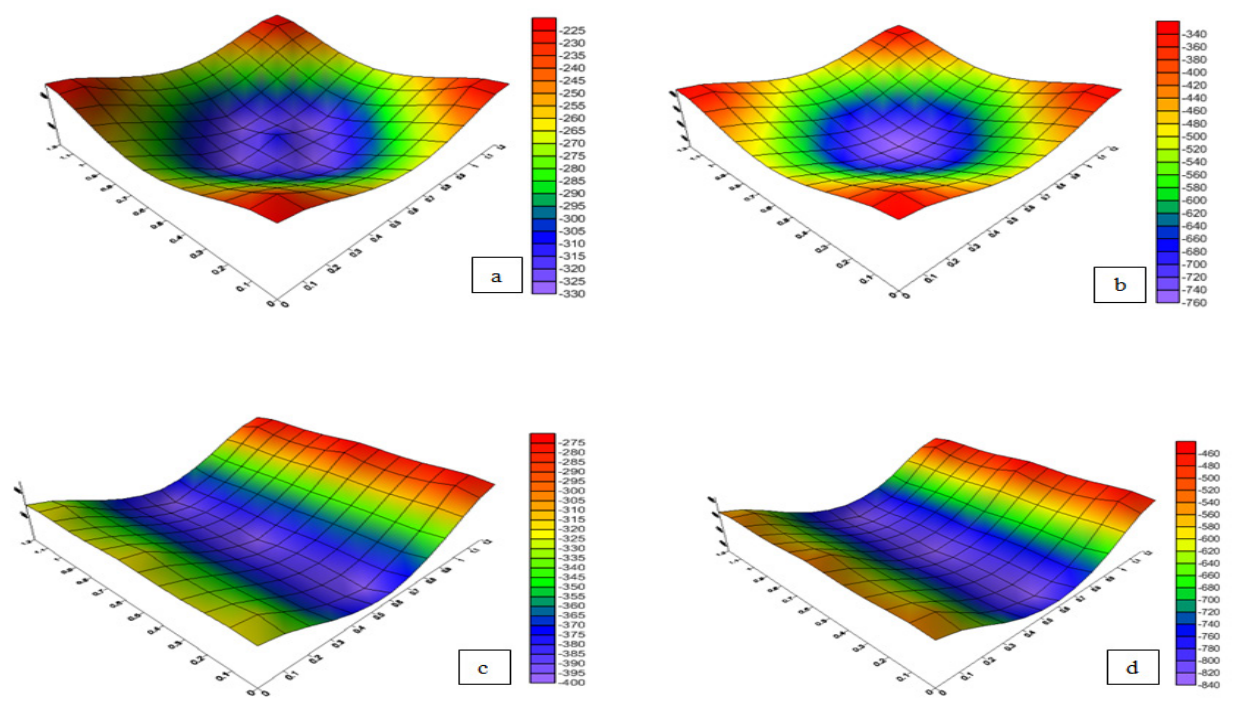

Figure 21: 3-D demonstration the contact stress distribution beneath control footings $\mathrm{C} 1$ and $\mathrm{C} 2$ (a) $50 \%$ of $\mathrm{C} 1$ failure load. (b) $100 \%$ of $\mathrm{C} 1$ failure load (c) $50 \%$ of $\mathrm{C} 2$ failure load. (d) $100 \%$ of $\mathrm{C} 2$ failure load.

\section{Summary and Conclusions}

In the current study, six isolated concrete footing were tested to evaluate the structural performance after strengthening for concentric and eccentric footing. From the test results, the increase in load-carrying capacities was calculated, the stresses and settlement distribution beneath control and strengthened footings were measured and the effect of using dowels in addition to epoxy bonding agent was evaluated an compared to the effect of using epoxy bonding agent only. The following conclusions are summarized:

- In both concentric and eccentric loading, the load-carrying capacities of strengthened footings were close to that of nonstrengthened ones with same dimensions.

- Using dowels to connect the existing footing to the concrete jacket did not increase the load-carrying capacity significantly compared to using bonding agent only.

- The contact stress distributions beneath control and strengthened footings were not consistent with the theoretical solutions, the assumption of uniformity solution gives expected higher moment than the actual results and leads to a conservative structural design.

- The stress concentration under column center was increased by average $10 \%$ and $15 \%$ for concentric and eccentric jacketing respectively compared to the control specimens.

- The increase in settlement after jacketing was approximately $6 \%$ and $3.5 \%$ for concentric and eccentric jacketing respectively compared to the control specimens.

- The contact stresses seem to be saddle-shaped before cracking and the concentration of stresses tend to be shifted towards the center of footing after cracking during concentric loading.

\section{Conflict of Interest}

The authors declare no conflict of interest.

\section{References}

[1] H.M. Algin, "Practical formula for dimensioning a rectangular footing," Engineering Structures, 29(6), 1128-1134, 2007, doi:10.1016/j.engstruct.2006.08.009. 
[2] G.T. Truong, K.K. Choi, H.S. Kim, "Punching-shear behaviors of RC-column footings with various reinforcement and strengthening details," Engineering Structures, 151, 282-296, 2017, doi:10.1016/j.engstruct.2017.08.037.

[3] J. Hegger, M. Ricker, B. Ulke, M. Ziegler, "Investigations on the punching behaviour of reinforced concrete footings," Engineering Structures, 29(9), 2233-2241, 2007, doi:10.1016/j.engstruct.2006.11.012.

[4] Z. Bonić, R. Folić, "Punching of column footings - Comparison of experimental and calculation results," Gradjevinar, 65(10), 887-899, 2013, doi:10.14256/jce.916.2013.

[5] P.J. Gusia, "A new European Standard on products and systems for Protection and Repair of concrete structures - EN 1504," IABSE Symposium Report, 93(22), 9-14, 2011, doi: 10.2749/222137807796120067.

[6] A.C.I. Committee, 318-19 Building Code Requirements for Structural Concrete and Commentary, 2019, doi: 10.14359/51716937.

[7] CSA/A23.3, Canadian Standard Association, Code for the design of concrete structures for buildings, CSA/A23.3-14, Toronto, Ontario, Canada, 2014.

[8] W.X. Zhang, B. Li, H.J. Hwang, J.Y. Zhang, L.J. Xiao, W. jian Yi, H.G. Park, "Punching shear strength of reinforced concrete column footings under eccentric compression: Experiment and analysis," Engineering Structures, 198(August), 2019, doi:10.1016/j.engstruct.2019.109509.

[9] W.H. Mosley, J.H. Bungey, Design of Reinforced Concrete Design, Macmillan Education UK, London: 154-191, 1990, doi:10.1007/978-1-34913058-0 7.

[10] T. Vacev, Z. Bonić, V. Prolović, N. Davidović, D. Lukić, “Testing and finite element analysis of reinforced concrete column footings failing by punching shear," Engineering Structures, 92, 1-14, 2015, doi:10.1016/j.engstruct.2015.02.027.

[11] Muller, G.U. "Photoelastic Determination of Contact Stresses of Foundations", Journal of Geotechnical Engineering, 122(8), 692-696, 1996, doi: 10.1061/(ASCE)0733-9410(1996)122:8(692)

[12] E.N.B.S. Júlio, D. Dias-da-Costa, F.A.B. Branco, J.M.V. Alfaiate, “Accuracy of design code expressions for estimating longitudinal shear strength of strengthening concrete overlays," Engineering Structures, 32(8), 2387-2393, 2010, doi:10.1016/j.engstruct.2010.04.013.

[13] E.N.B.S. Júlio, F.A.B. Branco, V.D. Silva, "Concrete-to-concrete bond strength: Influence of an epoxy-based bonding agent on a roughened substrate surface," Magazine of Concrete Research, 57(8), 463-468, 2005, doi:10.1680/macr.2005.57.8.463

[14] M.N. EL Siragy "Improving the ultimate capacity of loaded strip footing using additional contact area under excessive loads", Life Sci J, 16(12), 147153, 2019, doi:10.7537/marslsj161219.19

[15] Aiban, S. A., \& Znidarčić, D. "Centrifugal Modeling of Bearing Capacity of Shallow Foundations on Sands", Journal of Geotechnical Engineering, 121(10), 704-712, 1995, doi: 10.1061/ (ASCE) 07339410(1995)121:10(704)

[16] ASTM Standard D2487. "Standard Practice for Classification of Soils for Engineering Purposes", Unified Soil Classification System, 2011, doi: 10.1520/D2487-11.

[17] T. Gnananandarao, R.K. Dutta, V.N. Khatri, "Model studies of plus and double box shaped skirted footings resting on sand," International Journal of Geo-Engineering, 11(1), 2020, doi: 10.1186/s40703-020-00109-0.

[18] British Standard Institute, "BS EN 12390-3:2001 Testing hardened concrete Part 3: Compressive strength of test specimens," BSI Standards Publication, 4-10, 2001.

[19] ASTM International, "Standard Specification for Deformed and Plain Carbon-Steel Bars for Concrete Reinforcement," Aashto, M31, 6, 2016, doi: 10.1520/A0615.

\section{Notations}

- $f_{c u}$ : concrete Compressive Strength.

- $f_{y}$ : Steel Yield Stress.

- $\quad \mathrm{RC}$ : Reinforced Concrete.

- W: uniform distribution under footing (Force/Area).

- L: Distance between edge of columns and edge of footing. 